\title{
RUILWAARDE
}

RUILNOMMERS: „Tydskrif vir Geesteswetenskappe," geredigeer deur 'n aantal personeellede van die Universiteit van Pretoria onder leiding van prof. dr. H. P. Wolmarans, het 'n heeltemal nuwe fase begin. Vanaf Julie 1950 begin dit weer van vooraf met „Band 1, no 1." Dit is 'n besonder gocie en goed geredigeerde wetenskaplike blad. Die eerste nommer bevat enkele uitstekende studies. Ek noem maar net die volgende: A. M. T. Meyer oor die plek van die wysgerige antropologie in die filosofiese refleksie, $H$. P. Wolmarans oor die C.N. lewensbeskouing en sy implikasie en $P$. C. Coetzee oor kennisteoretiese subjek en objektiewe waardeleer. „Philosophia Reformata," orgaan van die vereniging vir Calvinistiese wysbegeerte, geredigeer vanuit die Vrye Universiteit, handhaaf nog altyd so 'n besonder hoë gehalte. Die uitgawe vir die $2 \mathrm{e}$ en 3e kwartaal 1950 bevat twee besonder swaar studies: S. U. Zuidewa se slot oor die eksistentialisme by Kierkegaard, en H. Dooyeweerd se substansiebegrip in die moderne natuurfilosofie en die teorie van die enkaptiese struktuurgeheel. Die uitgawe word besorg deur die firma J. H. Kok, Kampen. „Ons Eie Boek," 'n Afrikaanse boekegids onder redaksie van Francois Malherbe, verander so geleidelik tot ' $n$ breër publikasie; omdat dit algaande ook ander artikels gee as net bespreking van boeke. Sy rubriek „Artikels" is besonder goed: John Paris se Living "Art and Living People" en A. Uys se „Afrikaanse Kinderboeke" verdien spesiale vermelding. 
Na die artikels kom dan die "Kritiese Bulletin" oor boeke uit verskillende terreine en ten slotte die uiters waardevolle "Studies in Letterkunde" (twee oor Afrikaanse en twee oor Nederlandse werke). ( $\mathrm{Jg} . \mathrm{XVI}$, no. 2, 1050).

$$
* * *
$$

KERK EN GODSDIENS. Besonder min val daar diekeer op hierdie gebied te vermeld. Die belangrikste gebeure is seker die afskeid van prof. dr. J. D. du Toit as gereelde skrywer van die inleiers vir "Die Kerkblad" (so vermeld in die uitgawe van 22 September). S. du Toit het ' $n$ besonder grondige studie oor uitdaging aan die kerk in "Die Kerkblad" ( 8 Sept.). Van besondere betekenis is die spesiale nommer van "Die Gereformeerde Vaandel" (Aug.) oor kategismusprediking. Oor die nuut-ontdekte Jesajarolle is daar twee kort artikels: J. $H$. Kritzinger in „Die Kerkbode” (6 September, en A. van Selms in "Die Hervormer" (Sept.). In "Calvin Forum" (Junie-Julie) skryf J. Daane 'n mooi artikel oor "Church proclamation and the modern mind." En in "Horizon' (Julie-Augustus)) het E. D. Kraan dit oor "tweeërlei theodicee."

SKOOL EN OPVOEDING: Hier is die oes iets groter: Christelike en C.N. onderwys geniet nog steeds die volle aandag-P. N. Barnard in "Inspan" (Aug.), C. F. Hoogendyk in "Inspan" (Aug.), redaksie in "Christian Home and School" (Julie-Augustus), redak. sie „Die Unie (Sept.), M. J. v.d. Westhuizen in "Die Christelike Vrou" (Julie-Augustus). Die redaksie van "Die Kerkbode" (22 Sept.) het dit oor 'n teenwig teen die "Comics", en "Christian Life" (Julie) oor verraad in ons leerboeke. 'n Goed geïllustreerde reeks artikeltjies oor die sondagskool verskyn in "Christian Life"
(Sept.), J. N. Smit skryf in „Die Unie" (Aug.) oor die Kaaplandse kleuterskool-vereniging en $I$. van der Velde in "Paed. Studiën" (Julie-Augustus) oor die opleiding van kleuteronderwyseresse. F. H. Douma het 'n mooi tudie in "Onderwysblad" (Aug.) oor aaneenskakelende leergange in Afrikaans; en ook daar 'n artikel deur E. A. Venter oor dramatiese kuns op skool. J. Schutte skryf iets moois oor "Wat lees my kind" in ,Die Geref. Vroueblad" (Sept.). 'n Baie interessante artikel oor die ou skool op Franschhoek deur $P$. Roosen verskyn in „Die Huisgenoot" (25 Aug.) en een deur A. Smuts oor ouers en jongmense in „Die Brandwag" (8 Sept.).

\section{$* *$}

MAATSKAPPY, KUNS EN WETENSKAP. Op hierdie breë terrein is die bydraes vanselfsprekend meer en tans meer aktueel. Die groot ekonomiese kongres in Bloemfontein staan in die middelpunt van ons nuutste belangstellingsrigting. J. C. Bach word herdenk in meeste ruilnommers - „Die Kerkbode” (16, 23 Sept.), „Die Geref. Vroueblad” (Sept.), „Die Huisgenoot" (28 Julie), Die G. R. A. ontvang nog meer aandag-,Die Kerk bode" (23 Aug.), „Inspan” (Aug.) „Die Huisgenoot" (4 Aug.), „Die Brandwag” (11 Aug.), „Die Taalgenoot" (Aug.), „Zuid-Afrika” (Sept.), „Die Kerkblad" (Aug.). Die heengaan van Genl. Smuts op 11 Sept. is natuurlik 'n geweldige gebeurtenis in ons landdie een orgaan op die ander wy artikels aan hom: so is daar reeds in „Race Relations News" (Sept.), „Die Kerkbode" (20 Sept.) en veral "Die Huisgenoot" (29 Sept.) waarderende artikels oor hom. Die seksuele probleem word vanuit Christelike standpunt besien in "Die Kerkbode" (30 Aug.) deur D. F. de Beer, in ,Die Hervormer" (Aug.) deur J. J. Engel- 
brecht, in „Horizon” (Julie-Aug.) deur G. Brillenburg Wurth. "Sosiale Euwels," soos dobbel, bioskoop, verleiding, vind aandag in "Die Kerkbode" (2, 16 Aug.), in "Christian Life" (Julie), in „Die Kerkblad” (18 Aug.). Wêreldgebeure roer $J$. $D$. du $T$. in elke uitgawe van ,Die Kerkblad" in sy inleiers aan; en "Die Koreaanse oorlog" vind natuurlik orals bespreking. In „Die Huisgenoot” (8 Sept.) het L. I. Coertze 'n besonder mooi bydrae oor die eerste, tweede en derde Britse ryk. Ons jeug in die branding word bespreek in "Die Kerkbode" (30 Aug.), in "Die Taalgenoot" (Sept.), in „Horizon" (Julie-Aug.) en weer in „Die Kerkbode" (20 Sept.). S. J. v.d. Walt gaan in "Ons Kleintjie" (Sept.) voort met sy breed opgesette studle oor segregasie. S. U. Zuideman het dit in "Bezinning" (Julie-Aug.) oor 'n nuwe frontlinie (baie mooi!) A. F. Weich skryf mooi oor handel en ons naturelleprobleem in "Inspan" (Aug.). In "Calvin Forum" (Junie-Julie) is daar twee besonder belangrike bydraes: $\mathrm{C}$. B. oor franse Calvinisme, en die simposium oor Calvinisme en politieke aksie. F. v.d. Reyden skryf in "Die Brandwag" oor Lydenburg se eeufees (25 Aug., 1 Sept.): En eindelik, vervolg H. Blignault sy belangrike studie oor die geestesgesondheidsbeweging in Suid-Afrika in "Ons Kleintjie" (Sept.).

\section{J. CHR. COETZEE.}

